Commission Splits of Real Estate Agents with Affiliated Firms

By: Daniel T. Winkler, Bruce L. Gordon

Winkler, D. T. \& Gordon, B. L. (2013). Commission Splits of Real Estate Agents and Affiliated Firms. Journal of Housing Research, 22(2), 109-122.

Made available courtesy of the American Real Estate Society: http://www.aresnet.org/

***(C) American Real Estate Society. Reprinted with permission. No further reproduction is authorized without written permission from the American Real Estate Society.***

Keywords: Real Estate Agents | Sales Commissions | Profit Sharing | Salaries

***Note: Full text of article below 


\title{
Commission Splits of Real Estate Agents with Affiliated Firms
}

\author{
Daniel T. Winkler and Bruce L. Gordon
}

\section{Abstract}

The commission split between real estate agents and their affiliated firms represents an important incentive mechanism. A study of 1,477 agents indicates that total commission revenue generated during the year affects the subsequent commission rate more than volume of residential sales or transactions. Profit sharing and independent franchise firms offer higher ending commission splits while larger firms offer lower commission splits. The ending commission split for commission agents compared to agents on a $100 \%$ payout contract, however, is not influenced as much by profit sharing, firm characteristics, and the economic environment.

The real estate brokerage industry has received considerable criticism for not acting in the interests of their clients and more generally, in the public interest. The potential sources of this problem can be categorized into three areas: (1) state legislation with regard to the real estate agency relationship; (2) the presence of fixed commission rates in Multiple Listing Service (MLS) transactions; and (3) split commission arrangements between agents and their affiliated firms. Miceli, Pancak, and Sirmans (2000) suggest that problems with state legislation make buyers underrepresented, sellers unintentionally liable for actions of unknown subagents, and dual agency status often imposed after the fact. $^{1}$ The second problem has been extensively examined in studies such as Yinger (1981), Crockett (1982), and Miceli (1992); most of this research indicates that fixed commission rates appear to be above an equilibrium rate. ${ }^{2}$ The third problem represents a potential conflict of the principal/agent relationship. The agent/firm split affects the willingness of the agent to expend effort in listing and selling processes and perhaps the quality of the agent's work. Agents who do not receive an adequate split relative to their employing firm will certainly be less productive. ${ }^{3}$

Several empirical studies have investigated the factors that determine whether an agent decides to work on a split commission or $100 \%$ payout contract. Zumpano, Johnson, and Anderson (2009) and Chinloy and Winkler $(2010,2011)$ have identified determinants of choosing between these contracts. The broader question of relating an agent's split commission or $100 \%$ payout provision in one period to the next, however, has not been investigated in any detail. This research study investigates this question, controlling for agent and firm characteristics and market influences. The findings partially explain the basis for agent reward and success and the importance of factors that firms must consider for retaining and rewarding the most successful agents. 


\section{Literature Review}

The underpinnings of split commission contracts versus $100 \%$ contracts are based upon the agency theory in economics and finance literature. Alchian and Demsetz (1972) describe a similar relationship of shirking and monitoring in the context of team production. Unlike Coase (1937), Alchian and Demsetz consider team production, organization, monitoring, and shirking problems as fundamental to their explanation of the firm. Jensen and Meckling (1976) describe the problem of shirking by employees of a firm, as well as the mechanisms to monitor and control shirking, which often result in higher costs to the firm. Aligning the interests of agents as managers and shareholders as principals through effective incentives and contracting can reduce shirking.

The concepts of principal-agent relationships have been examined in the real estate literature for more than 30 years. Yinger (1981) develops a search model to explain the market for broker services, the role of the MLS, and broker commission rates. A primary conclusion is that the brokerage industry is not efficient, and that fixed commission rates contribute to this problem. Wu and Colwell (1986) and Zorn and Larsen (1986) suggest, however, that a commission rate contract partially overcomes the problem of not being able to monitor an agent's activities. Miceli (1989) argues that a limited duration contract can overcome moral hazard from the seller's perspective. Waller, Brastow, and Johnson (2010) expand on Miceli's length of contract study, and find that a longer listing contract period decreases broker effort, which results in lower search intensity by the broker and an increase in marketing time. Geltner, Kluger, and Miller (1991) suggest that a finite duration listing contract creates the incentive for agents to increase effort towards the end of the contract, and that there can be a serious conflict of interest regarding the reservation price, particularly at the end of the contract. Clauretie and Daneshvary (2008) examine the tendency of brokers to increase their efforts to generate more potential buyers, and perhaps higher offering prices, with the possible incentive to reduce the reservation price. They find that the price-reduction effect dominates the broker effort with a negative price effect of about $0.5 \%$ per month. Anglin and Arnott (1991) analyze the brokerage contract between the house seller and agent (broker) using the established principal-agent literature and find that standard commission contracts fail to allocate risk efficiently or provide appropriate incentives for agents. Yavas (1995) examines the sellerbroker relationship in terms of a double moral hazard problem where there are unobservable efforts of both sellers and agents, finding that the outcomes depend on the interactions between the actions of the players.

Several studies have examined $100 \%$ commission payout contracts versus split commission contracts as they relate to the effect on housing prices, time on the market (TOM), and listings acquired. Munneke and Yavas (2001) develop a theoretical model based upon the proposition that agents maximize total commissions. Agents on $100 \%$ contracts should have more incentive to acquire listings and market properties. Their findings indicate that the $100 \%$ contract agents have acquired an average of 30 listings versus 18 for traditional agents, a statistically significant difference. The $100 \%$ contract agents, however, did not have a statistically lower TOM. As predicted, 100\% contract agents were not able to obtain higher selling prices for their clients. In contrast, Allen, Faircloth, Forgey, and Rutherford (2003) find that 100\% contract agents' properties are 
sold more quickly and at a premium relative to properties sold by agents on split commission. Johnson, Zumpano, and Anderson (2008) re-examine TOM and selling price, but instead of assuming that all $100 \%$ contract agents work for RE/MAX, they include agents working for non-RE/MAX firms who also work on $100 \%$ contracts. They find that $100 \%$ contract agents sell their listings about 35 days sooner ( $41 \%$ quicker) and at a 5.8\% premium. Zumpano, Johnson, and Anderson (2009) compare agent and firm characteristics for agents on a split contract versus those on $100 \%$ contracts. Their findings indicate that $100 \%$ contract agents are more experienced, have a shorter tenure with their current firm, and earn more income than split commission agents. These agents are more likely to be male and work in sales offices with a larger staff. Similar to Zumpano, Johnson, and Anderson (2009), Chinloy and Winkler (2010) develop a probit model in the first step of their wages and hours worked models in an effort to control for sample selection bias. The probit equation empirical results support the positive relationship of experience and male gender as important determinants of agents on $100 \%$ contracts. They also find that agents who work in larger firms are more likely to be on split contracts. Chinloy and Winkler (2011) use a bivariate probit model with $100 \%$ versus split contracts and ownership versus non-ownership. Their findings support earlier work; however, they find that residual income (household income minus real estate income) is negatively related to agents choosing to work on a $100 \%$ contract, which is contrary to the findings of Zumpano, Johnson, and Anderson (2009).

\section{Methodology}

Firms contract with an individual agent and receive a portion of the revenue generated by the agent. In some cases the firm may also charge agents a fixed periodic fee in lieu of, or in addition to, a portion of the revenue. Based upon the agent's productivity, a firm may be willing to change the contract in the next period to a higher split if the agent is expected to produce sufficient revenue to justify the split increase. If not, the firm may require the agent to assume more of the expenses. The firm may also agree to a higher split for the agent even if revenue increases or expense decreases for the firm do not make the firm's profit increase. This might occur if there were externalities that affected the willingness of the agent to work with other agents to generate additional revenue for the firm as a whole.

The empirical specification for sales professional productivity is measured by the ending commission percentage as follows:

$$
Y_{i}=\alpha_{0}+\mathbf{X}_{1} \boldsymbol{\beta}_{1}+\mu_{i}
$$

where $Y_{i}$ is the percentage ending period commission, $\mathbf{X}_{1}$ is the matrix of exogenous explanatory variables with regression coefficient matrix $\boldsymbol{\beta}_{\mathbf{1}}$ and intercept $\alpha_{0}$. The error term is defined as $\mu_{i}$.

The $\mathbf{X}_{1}$ matrix includes the beginning contract percentage that is split between the agent and the firm and various explanatory variables that control for agent, firm, and market environment characteristics. The Appendix lists and describes the variables.

The beginning contract rate that is set at the start of the year is assumed to encapsulate the performance characteristics of the agent. These would include the agent's experience, 
hours worked, previous sales transaction, and revenue production, among other variables. ${ }^{4}$ The end of period split contract percentage, however, may be revised based upon the performance of the agent during the contract period, changes in professional characteristics of the agent such as being a manager agent or broker-owner (with selling responsibilities), and job changes. ${ }^{5}$ The agent's performance in the period can be measured in terms of total revenue, total dollar sales, or number of transactions, all of which are expressed in natural logarithms. These performance measures are separately tested, and all are expected to be positively related to the ending commission split. Agents who are also managers are likely to receive a lower commission split since they are engaged in managerial tasks that are typically compensated by salary. An ownership interest may increase the ending commission split as it represents the additional ability of the agent. ${ }^{6}$ Agents who are dissatisfied with their contract provisions may change jobs, which could lead to a change in their contract split. The motivation of the agent might be affected by the amount of household non-real estate income as measured by the natural logarithm of residual income. Agents who have more residual income may have less interest and incentive to work to generate commission income.

Periodic business expenses are incurred by the agent, including fees paid to the firm. The agent on a $100 \%$ payout contract will pay the firm a fixed periodic expense, but even before reaching a $100 \%$ payout contract, a firm may pay for fewer expenses as the agent receives a greater split of the revenue. Firms generally pay more of the expenses for agents in training. As they become more skilled, it is expected that agents become more productive by selling more property and generating more commission revenue for themselves and the firm. More skilled agents should have higher business expenses, but their expenses per transaction should fall as they become more productive. To compensate for differences in productivity among agents, business expense should be estimated relative to productivity, as business expenses should increase with more transactions, but because some expenses are fixed, the cost per transaction should fall. However, business expenses are endogenous, and therefore, 2SLS is used to estimate business expenses on a per transaction basis. ${ }^{7}$

A firm's characteristics and the market environment may influence the contract that is offered. These factors include firm size as indicated by the natural logarithm of the number of firm offices, whether the firm is an independent franchise (not affiliated with a national or regional franchise), and whether the firm offers profit sharing. Larger firms may offer smaller splits than smaller firms because they can offer benefits such as higher levels of support staff, training, and the prospect of more sales income from their greater name recognition. Independent franchise firms may offer larger splits to attract better agents because they do not possess the advantages of name recognition and national advertising, but do have the flexibility to offer larger splits to more productive agents. In addition, franchises charge a fee, typically subtracted from the gross commission before applying the split. Presumably the franchise provides sufficient benefits to offset the franchise fees. ${ }^{8}$

The market environment could affect contract terms as well. These environmental factors include the price level of the housing market as measured by the natural logarithm of the median metropolitan single family house prices, total employment in the metropolitan area, and the percentage change in employment. Competition for highly qualified agents 
may result in larger splits for agents in areas with higher metropolitan housing prices. Positive changes in metropolitan employment should increase commission splits for agents since firms are able to pay agents more and still remain profitable in areas with growth. The effect of metropolitan size on ending commission splits is less clear. While larger metropolitan areas should have more competition for agents, which might result in an increase in the commission split, transaction activity may be larger with higher selling prices, increasing the number of agents willing to work in larger areas and decreasing the split that firms need to offer.

\section{Data}

The data on real estate agent contracts are from the 2008 National Association of Realtors ${ }^{\circledR}$ (NAR) Member Survey. The member survey represents a random sample of individuals in a variety of real estate occupations, including sales agents and brokers, for the 2007 calendar year. In February 2008, NAR mailed the 89-question survey to 72,000 Realtors, and in addition, an identical web-based online survey was distributed to a group of 89,400 members. After correcting for undeliverable questionnaires, 9,997 responses were received, for an adjusted response rate of $7.7 \%$. Agents included in the sample primarily engage in residential real estate sales; these sales produce at least $50 \%$ of their income. Median single-family home prices were also provided by NAR, and employment data was obtained from the Bureau of Labor Statistics. These supplementary data sets are matched by ZIP Code with the NAR survey data. After deleting mis-coded data, applying the residential agent restriction, and merging the market data for regression analysis, the final sample decreased to 1,477 observations when including all agents (split commission and $100 \%$ commission payout), 1,264 observations including agents only on split commission at the beginning of the year, and 1,182 observations for agents beginning and ending on split commissions.

The summary statistics are shown in Exhibit 1. For the split commission sample, agents have a mean commission split of $66.3 \%$, with an ending split at $70.9 \%$. The commission split percentage represents the portion of the commission received by the agent with the remaining portion going to the firm. The average split increased about $4.6 \%$ for these agents during the year. However, the mean split is an underestimate of the percentage payout for all agents because some agents chose to move to a $100 \%$ payout where they pay a fixed, periodic fee to the firm. The number of $100 \%$ payout agents in the sample is 310 or $12 \%$ of the total sample.

\section{Findings}

Exhibit 2 reports the ending commission heteroscedastic-consistent estimator regression results for all agents. ${ }^{9}$ In Model 1 , the dependent variable is agent total productivity as measured by the natural logarithm of total commission revenue generated by the agent; this commission is split by the agent with the firm, or for $100 \%$ payout agent contracts, kept entirely by the agent. The two alternative measures of productivity reported in the last two sets of columns include the natural logarithm of residential sales (Model 2) and the natural logarithm of the annual number of residential transactions (Model 3). 


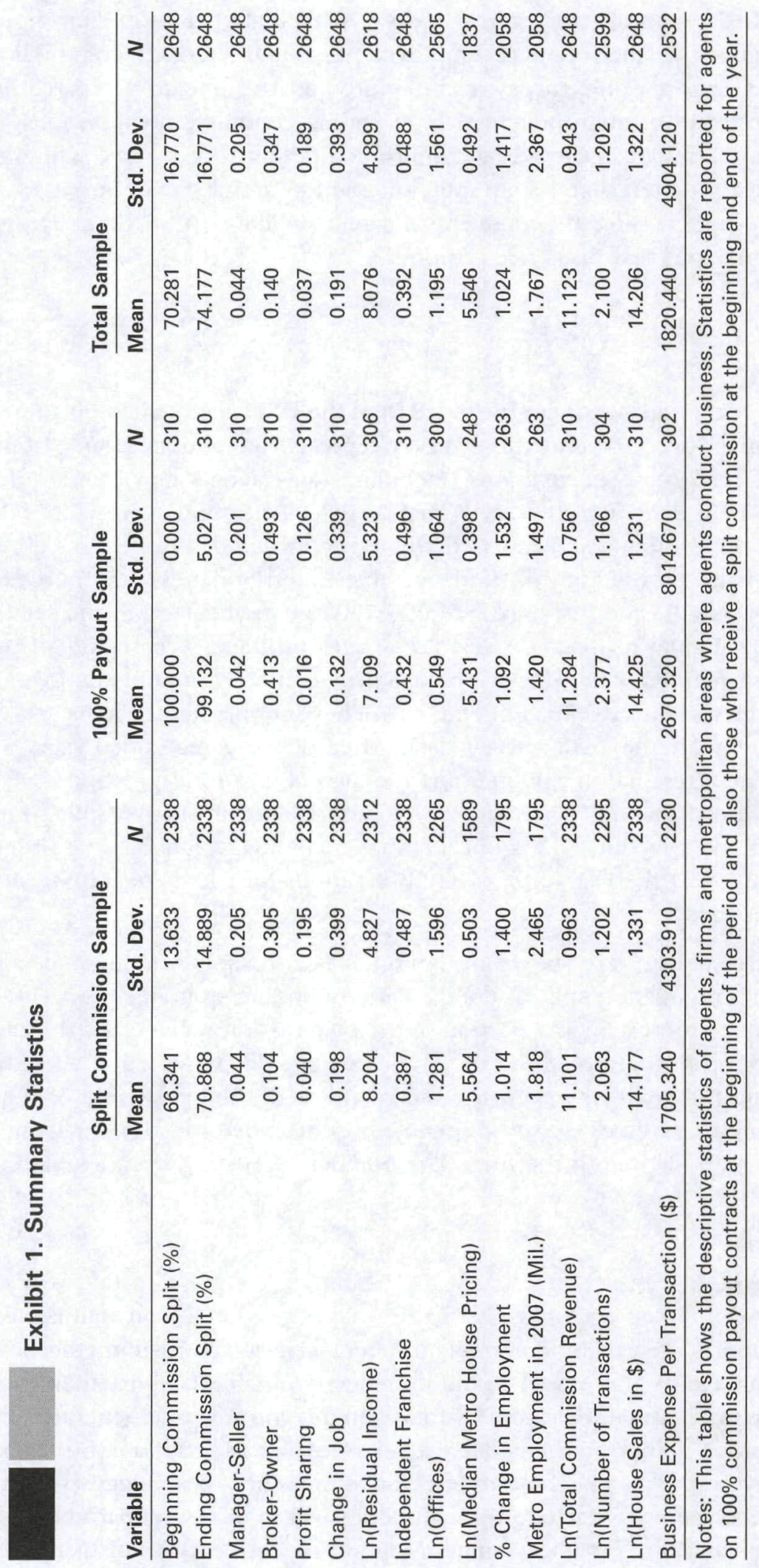




\section{Exhibit 2. 2SLS Regression of the Ending Commission Rate for All Agents}

\begin{tabular}{|c|c|c|c|c|c|c|}
\hline \multirow[b]{2}{*}{ Variable } & \multicolumn{2}{|l|}{ Model 1} & \multicolumn{2}{|l|}{ Model 2} & \multicolumn{2}{|l|}{ Model 3} \\
\hline & Coeff. & T-ratio & Coeff. & T-ratio & Coeff. & T-ratio \\
\hline Constant & $-24.4855^{* *}$ & -5.443 & -9.4196 & -1.948 & 6.0444 & 1.666 \\
\hline Beginning Commission Split (\%) & $0.7512^{* *}$ & 41.387 & $0.7615^{* *}$ & 38.331 & $0.7481^{* *}$ & 38.431 \\
\hline Ln(Total Commission Revenue) & $3.4659 * *$ & 10.428 & - & - & - & - \\
\hline $\operatorname{Ln}($ House Sales in \$) & - & - & $1.3137 * *$ & 5.242 & - & - \\
\hline Ln(No. House Transactions) & - & - & - & - & $1.8335^{* *}$ & 4.480 \\
\hline Manager-Seller & $-4.3654 * *$ & -4.471 & $-3.5188 * *$ & -3.592 & $-2.7197^{* *}$ & -2.912 \\
\hline Broker-Owner & -0.4472 & -0.639 & 0.5418 & 0.648 & -0.5811 & -0.805 \\
\hline Profit Sharing & $5.0245^{* *}$ & 2.969 & $5.4420 * *$ & 2.859 & $4.1247^{*}$ & 2.315 \\
\hline Change in Job & 0.5596 & 0.809 & -0.6029 & -0.783 & -0.8054 & -1.210 \\
\hline Ln(Residual Income) & -0.0280 & -0.498 & $-0.1282 *$ & -2.065 & $-0.1223^{*}$ & -2.162 \\
\hline Independent Franchise & $1.5047^{* *}$ & 2.671 & $1.9001 * *$ & 2.962 & $1.3207^{*}$ & 2.279 \\
\hline $\operatorname{Ln}$ (Offices) & $-0.5317 * *$ & -3.429 & $-0.5471 * *$ & -3.269 & $-0.4872 * *$ & -3.178 \\
\hline Ln(Median Metro House Pricing) & $1.8283^{* *}$ & 2.617 & $2.9108 * *$ & 3.677 & $2.5759 * *$ & 3.655 \\
\hline \% Change in Employment & $0.4624^{*}$ & 2.141 & $0.5878 *$ & 2.445 & $0.5212^{*}$ & 2.304 \\
\hline Metro Employment in 2007 (Mil.) & $-0.6083 * *$ & -5.287 & -0.6506 & -5.056 & $-0.5291^{* *}$ & -4.544 \\
\hline Business Expense Per Transaction & $-0.0005 * *$ & -2.268 & $-0.0011^{* *}$ & -3.675 & 0.0002 & 0.478 \\
\hline Adj. $R^{2}$ & 0.67 & & 0.58 & & 0.67 & \\
\hline F-Test & 230.99 & & 152.79 & & 232.43 & \\
\hline
\end{tabular}

Notes: This table reports the regression results for the determinants of the ending commission rate for 1,477 agents who are either on a split commission or $100 \%$ contracts. Model 1 uses total commission revenue generated during the year to measure agent productivity. Model 2 uses the dollar value of house sales, and Model 3 uses the number of transaction sides. The number of observations in all models is 1,477 .

* Statistically significant at the 0.05 level.

** Statistically significant at the 0.01 level.

However, because the firm is expected to maximize commission revenue received rather than gross residential sales or the number of transactions, the focus will be on commission revenue. The F-tests for the three regressions are all statistically significant at the 0.01 level. The adjusted R-squares of the regressions explain about two-thirds of the variation in the ending commission split rates.

The findings in Exhibit 2 suggest that the beginning commission rate is strongly related to the ending commission split rate. That is, that new commission split is based upon the existing rate. The ending split changes by $0.75 \%$ per $1 \%$ change in the beginning rate. Agent productivity during the year affects the ending rate; as productivity increases so does the ending split rate. Total commission revenue appears to have the strongest influence on the ending split rate. Manager-sellers receive about a $4.4 \%$ lower split, while firms offering profit sharing also have a 5\% higher split. This suggests that agents who work and receive profit sharing are likely more productive than the average agent. Brokerowner status and agents who change their job did not have statistically different split 
commission rates than others in the sample after controlling for other influences. While there is some evidence that agents in households with higher residual income have lower split rates, the coefficient is not statistically significant in Model 1.

Firm characteristics and the market environment appear to influence the ending commission split rate. Independent franchise firms offer larger splits while larger firms offered smaller splits. One explanation is that independent franchises may employ higher skilled, more experienced agents while larger company-owned firms have well-established training programs in place, enabling them to more cost effectively and efficiently train agents and to employ less skilled, more inexperienced agents. Another explanation is that independent firms have less name recognition so they must offer larger splits to attract agents. The economic and market environment influences splits as well. A 1\% increase in employment in a metropolitan area is associated with a $0.46 \%$ increase in the split for the agent, while larger metropolitan markets offer about a $0.6 \%$ reduction in the split rate per 1 million people employed. The larger volume of transactions in major metropolitan markets may enable firms to reduce the split to agents and retain a larger portion for the firm. In addition to higher house prices in metro areas, which generate higher commissions for these agents, the larger supply of agents who work in larger metro areas leads to more competition among agent, resulting in a lower agent splits.

The findings also suggest that more productive agents who sell more properties and lower their business expenses per transaction also receive a larger commission split. However, the coefficient for business expenses per transaction is not statistically significant for Model 3, which measures productivity in terms of the number of house transaction sides instead of in dollars. ${ }^{10}$ Therefore, the most productive agents are not only lowering their cost per transaction, but firms are rewarding them by offering them a greater split. ${ }^{11}$

The pool of all agents in Exhibit 2 includes some on $100 \%$ payout contracts at the beginning of the year. Many of these agents are independent contractors, and therefore, they have self-selected to receive a $100 \%$ payout contract in exchange for the payment of periodic fees. Exhibit 3 shows the regression findings for the sample of agents who were on split commission at the beginning of the year. These agents choose either to remain on a split contract with their firm or move to a $100 \%$ payout contract by the end of the year. Agents who start on a 100\% payout contract are excluded from this sample.

The regressions in Exhibit 3 are all statistically significant at the 0.01 level. However, while the regression R-squares are still robust and range from 0.40 to 0.54 , they are significantly lower than the full sample. The difference in the overall fit of the regression is also evident in the smaller F-values. The key coefficient that became weaker in explaining the ending commission split is the commission at the beginning of the year; this coefficient is smaller and although highly statistically significant, it has a much smaller T-value. The other variable coefficients have larger magnitudes (positive and negative) compared to their counterparts in Exhibit 2.

The regressions shown in Exhibit 4 limit the underlying sample to agents who were on a split commission both at the beginning and end of the year. Therefore, agents who self- 


\section{Exhibit 3. 2SLS Regression of the Ending Commission Rate for Agents on Split Commission at the Beginning of the Year}

\begin{tabular}{|c|c|c|c|c|c|c|}
\hline \multirow[b]{2}{*}{ Variable } & \multicolumn{2}{|l|}{ Model 1} & \multicolumn{2}{|l|}{ Model 2} & \multicolumn{2}{|l|}{ Model 3} \\
\hline & Coeff. & T-ratio & Coeff. & T-ratio & Coeff. & T-ratio \\
\hline Constant & $-29.2566^{* *}$ & -5.926 & $-13.6602^{*}$ & -2.552 & 4.6352 & 1.163 \\
\hline Beginning Commission Split (\%) & $0.7145^{* *}$ & 29.017 & $0.7323^{* *}$ & 26.656 & $0.7167^{* *}$ & 26.260 \\
\hline Ln(Total Commission Revenue) & $3.9135^{* *}$ & 10.577 & - & - & - & - \\
\hline Ln(House Sales in \$) & - & - & $1.6135^{* *}$ & 5.493 & - & - \\
\hline Ln(No. House Transactions) & - & - & - & - & $2.0830 * *$ & 4.459 \\
\hline Manager-Seller & $-4.5394^{* *}$ & -4.253 & $-3.6535^{* *}$ & -3.343 & $-2.6292 * *$ & -2.612 \\
\hline Broker-Owner & -1.6485 & -1.653 & -0.0447 & -0.037 & -1.6154 & -1.526 \\
\hline Profit Sharing & $5.7131 * *$ & 3.229 & $6.0183^{* *}$ & 2.994 & $4.6421 *$ & 2.499 \\
\hline Change in Job & 0.9855 & 1.277 & -0.3981 & -0.473 & -0.5747 & -0.766 \\
\hline Ln(Residual Income) & -0.0437 & -0.660 & $-0.1633^{*}$ & -2.234 & $-0.1533^{*}$ & -2.297 \\
\hline Independent Franchise & $1.6423^{*}$ & 2.555 & $2.0619^{* *}$ & 2.802 & $1.4923^{*}$ & 2.285 \\
\hline $\operatorname{Ln}($ Offices $)$ & $-0.5578 * *$ & -3.425 & $-0.5917^{* *}$ & -3.350 & $-0.5227^{* *}$ & -3.277 \\
\hline Ln(Median Metro House Pricing) & 2.2637 & 2.899 & $3.3204^{* *}$ & 3.743 & $3.1422 * *$ & 4.079 \\
\hline$\%$ Change in Employment & 0.4802 & 1.885 & $0.6374^{*}$ & 2.231 & $0.5770 *$ & 2.165 \\
\hline Metro Employment in 2007 (Mil.) & $-0.6738^{* *}$ & -5.369 & $-0.7144^{* *}$ & -5.073 & $-0.5747^{* *}$ & -4.542 \\
\hline Business Expense Per Transaction & $-0.0005^{*}$ & -2.297 & $-0.0011 * *$ & -3.464 & 0.0002 & 0.495 \\
\hline Adj. $R^{2}$ & 0.54 & & 0.40 & & 0.54 & \\
\hline F-Test & 113.16 & & 64.79 & & 114.32 & \\
\hline
\end{tabular}

Notes: This table reports the regression results for the determinants of the ending commission rate for 1,264 agents who are on a split commission contract at the beginning of the year. Model 1 uses total commission revenue generated during the year to measure agent productivity. Model 2 uses the dollar value of house sales, and Model 3 uses the number of transaction sides. The number of observations in all models is 1,264 .

* Statistically significant at the 0.05 level.

** Statistically significant at the 0.01 level.

select to work on $100 \%$ payout contracts are excluded from the regression. In essence, this sample is "pure" because it excludes those who self-determine their commission payout at the end of the period. However, it does introduce the bias of excluding many high performers who choose to work on $100 \%$ payout contracts. In addition, for many agents a $100 \%$ payout is only available by changing firms. These regression models generally have the highest adjusted R-square statistics compared to the findings in Exhibits 2 and 3. The sample size is reduced because of the omission of all $100 \%$ payout agents, which reduces the F-values. All models are statistically significant at the 0.01 level.

The coefficient values and statistical significance levels for the split-commission agent sample in Exhibit 4 are quite different than those reported in Exhibits 2 and 3. The beginning commission split coefficient has a higher responsiveness in explaining the ending commission split, and the coefficients have high T-values. However, the effect of being a manager-seller does not reduce the ending commission split as much, while being 


\section{Exhibit 4. 2SLS Regression of the Ending Commission Rate for Split Commission Agents Only}

\begin{tabular}{|c|c|c|c|c|c|c|}
\hline \multirow[b]{2}{*}{ Variable } & \multicolumn{2}{|l|}{ Model 1} & \multicolumn{2}{|l|}{ Model 2} & \multicolumn{2}{|l|}{ Model 3} \\
\hline & Coeff. & T-ratio & Coeff. & T-ratio & Coeff. & T-ratio \\
\hline Constant & $-13.6895^{* *}$ & -3.640 & $-3.7108^{* *}$ & -0.915 & $8.5498^{*}$ & 2.529 \\
\hline Beginning Commission Split (\%) & $0.7775^{* *}$ & 40.798 & $0.7903^{* *}$ & 40.082 & $0.7731^{* *}$ & 31.035 \\
\hline Ln(Total Commission Revenue) & $2.5753^{* *}$ & 9.120 & - & - & - & - \\
\hline Ln(House Sales in \$) & - & - & $1.0981 * *$ & 5.163 & - & - \\
\hline Ln(No. House Transactions) & - & - & - & - & $1.6024 * *$ & 3.599 \\
\hline Manager-Seller & $-2.5147^{* *}$ & -2.985 & $-1.8663^{*}$ & -2.276 & -1.1469 & -1.375 \\
\hline Broker-Owner & $-2.1261^{* *}$ & -3.267 & -1.0139 & -1.420 & $-2.4308 * *$ & -2.810 \\
\hline Profit Sharing & 1.3225 & 1.157 & 1.2454 & 1.076 & 0.2285 & 0.164 \\
\hline Change in Job & 0.3523 & 0.607 & -0.5226 & -0.891 & -0.6056 & -0.990 \\
\hline Ln(Residual Income) & 0.0280 & 0.581 & -0.0530 & -1.023 & -0.0326 & -0.626 \\
\hline Independent Franchise & 0.6193 & 1.339 & 0.8559 & 1.706 & 0.4059 & 0.800 \\
\hline $\operatorname{Ln}$ (Offices) & $-0.3558^{* *}$ & -3.221 & $-0.3603^{* *}$ & -3.054 & $-0.3249 * *$ & -2.807 \\
\hline Ln(Median Metro House Pricing) & 0.8025 & 1.295 & $1.4181^{*}$ & 2.185 & $1.3032^{*}$ & 2.015 \\
\hline \% Change in Employment & -0.0398 & -0.205 & 0.0392 & 0.195 & -0.0369 & -0.167 \\
\hline Metro Employment in 2007 (Mil.) & $-0.2897 * *$ & -3.014 & $-0.3029 * *$ & -2.960 & -0.2004 & -1.942 \\
\hline Business Expense Per Transaction & 0.0000 & -0.120 & $-0.0004^{*}$ & -2.029 & 0.0006 & 1.577 \\
\hline Adj. $R^{2}$ & 0.71 & & 0.66 & & 0.67 & \\
\hline F-Test & 221.35 & & 181.09 & & 181.36 & \\
\hline
\end{tabular}

Notes: This table reports the regression results for the determinants of the ending commission rate for 1,182 agents who are on a split commission contract at the beginning and end of the year. Model 1 uses total commission revenue generated during the year to measure agent productivity. Model 2 uses the dollar value of house sales, and Model 3 uses the number of transaction sides. The number of observations in all models is 1,182 .

* Statistically significant at the 0.05 level.

** Statistically significant at the 0.01 level.

a broker-owner has a statistically significant negative effect compared to combined samples in Exhibits 2 and 3. The effect of independent franchise status, median metro house prices, and change in employment are not statistically significant in the split commission only sample. Perhaps most notable is that the business expense per transaction variable does not have a negative and statistically significant effect on the ending commission rate as it does for samples shown in Exhibits 2 and 3. So while this variable is important in explaining ending commission rates for those on $100 \%$ payout commission, it is not as important in explaining ending commission rates for splitcommission agents. One reason may be that agents on split-commission contracts have many, if not most of their expenses, paid by their affiliated firm while those on $100 \%$ payout contracts must pay business expenses themselves. Agents on $100 \%$ payout contracts must meet their fixed expense threshold and the ability of these agents to limit business expenses per transaction is a key component to profitability and net income generation. 


\section{Conclusion}

The commission split between the agent and the affiliated firm represents an important principal/agent relationship in real estate brokerage. The findings indicate that total commission revenue generated is more important in changing the subsequent commission rate than dollar house sales or the number of transactions. For the whole sample, managers (with selling responsibilities) have a $4.4 \%$ lower commission rate compared with those without managerial duties. A particularly interesting finding is that profit sharing firms also have higher ending commission splits. Larger firms offer lower commission rates while independent firms have higher ones. While increases in employment increase the commission split, commission splits are lower in larger metropolitan areas. For the entire sample, commission splits are inversely related to business expenses per transaction, suggesting that firms consider the agent's expenses when offering an agent-firm commission split. However, the ending commission rate is not responsive to the business expenses per transaction for the sample of split commission agents. In general, the ending commission rate for split commission agents is not influenced as much by profit sharing, firm characteristics, or the economic environment.

There are several important limitations of the study. First, the sample excludes part-time agents because of data constraints, and also, because of inherent differences between fulltime and part-time agents. Benjamin, Chinloy, and Winkler (2009) find that the magnitude of coefficients for agents on a $100 \%$ payout versus those on split contracts differ substantially between full- and part-time agents, requiring the estimation of separate probit models. Second, the time frame for this study is one year. Because real estate transactions often take months to complete, it would be advantageous to extend the analysis over multiple years. Third, the data consists of observations from 2007, which precedes the collapse of the housing bubble. It is possible that the relationship between commission splits and the explanatory variables in this study has fundamentally changed since the housing crisis. Future research should address these limitations.

\section{Appendix}

\section{Definition of Variables}

\section{Variable}

Commission Split

Beginning Commission Split (\%)

Ending Commission Split (\%)

Agent Characteristics

Manager-Seller

Broker Owner

Profit Sharing

Change in Job
Explanation

Commission split at the beginning of 2007.

Commission split at the end of 2007.

A dummy variable indicating if the agent has managerial responsibilities (Manager-Seller $=1$ ).

A dummy variable indicating if the agent is a broker-owner (Broker Owner = 1).

A dummy variable indicating that the firm has profit sharing (Profit Sharing $=1$ ).

A dummy variable indicating the agent has changed jobs in 2007 (Job Change $=1$ ) 
Variable

Ln(Residual Income)

Ln(Total Commission Revenue)

Ln(Number of Transactions)

Ln(House Sales)

Business Expense Per Transaction

Firm and Environment Independent Franchise

Ln(Offices)

Ln (Metro Median House Price)

\% Change in Employment

Metro Employment in 2007 (Mil.)

\section{Explanation}

The natural logarithm of the agent's residual income in 2007.

The natural logarithm of total commission revenue generated by the agent in 2007

The natural logarithm of the number of sides transacted by the agent in 2007.

The natural logarithm of dollar sales of houses transacted by the agent in 2007.

Total business expenses divided by the number of sides transacted in 2007.

A dummy variable indicating independent franchise firm status (Independent Franchise Firm = 1).

The natural logarithm of the number of real estate firm offices. The natural logarithm of the median metropolitan house price (house price in \$000).

The percentage change in employment in the metropolitan area. Total employment in the metropolitan area in 2007.

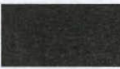

\section{Endnotes}

${ }^{1}$ Many researchers have proposed substantive remedies to the current system (e.g., Zorn and Larsen, 1986; Miceli, 1989, 1995; Anglin and Arnott, 1991; Arnold, 1992; and Jares, Larsen, and Zorn, 2000).

${ }^{2}$ A related concern to fixed commission rates is that the splitting of commission between listing and selling agents is not optimal. Miceli (1991) contends that that the splitting of the commission rate between listing and selling agents avoids costly races to acquiring listings. Agents cooperate with each other, but possibly at the expense of sellers. Miceli, Pancak, and Sirmans (2007) show that in the matching of buyers and sellers stage, split commissions in MLS transactions result in wasteful competition for listings.

3 There is also evidence that the agent/firm split may be related to the TOM and selling prices of houses (Munneke and Yavas, 2001; Allen, Faircloth, Forgey, and Rutherford, 2003; Johnson, Zumpano, and Anderson, 2008).

${ }^{4}$ The use of a beginning commission rate greatly reduces the number of variables needed to properly specify the model, thereby decreasing collinearity among the variables.

5 The changing of a job to another firm may also capture the job satisfaction of the agent.

${ }^{6}$ However, it could be argued that owners may lower their commission and instead take perquisites instead. Owners may also consider the tax consequences of receiving commission income versus allowing the income to flow through the firm. While previous research indicates that owners are generally more experienced than non-owners, it is not necessarily true that owners make the best agents.

7 The first-stage regression of the business expenses per transaction as the dependent variable is estimated using additional instruments including agent age and experience, real estate sales as a second career, and productivity measures including sales and number of house transactions.

${ }^{8}$ Franchise fees have been as high as $8 \%$. For example, some RE/MAX offices offer a $100 \%$ commission, which is applied only after $5 \%$ of the gross commission is taken off the top, resulting in what it is really a $95 / 5$ contract for the agent.

9 All regression coefficients reported in Exhibits 2, 3, and 4 are corrected for heteroscedasticity using the White (1980) method. 
10 The number of house transactions appears in the denominator of the business expense per transaction variable; this may explain why it is not statistically significant in Model 3 where productivity is defined in terms of the number of house transactions, while it is statistically significant in the other two models.

${ }^{11}$ It is possible that the more productive agents are also reducing the business expenses per transaction for the firm as well, or alternatively, that they are shifting more costs to the firm. The latter case is more dramatic as firms would be willing to offer a larger split despite shifting these expenses to the firm, although it seems unlikely to occur as firms would resist incurring these expenses. Business expenses incurred by firms on behalf of their agents, however, are not known.

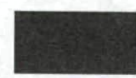

\section{References}

Alchian, A.A. and H. Demsetz. Production, Information Costs, and Economic Organization. American Economic Review, 1972, 62:5, 777-95.

Allen, M.T., S. Faircloth, F. Forgey, and R.C. Rutherford. Salesperson Compensation and Performance in the Housing Market. Journal of the Academy of Finance, 2003, 1:2, 62-71. Anglin, P.M., and R. Arnott. Residential Real Estate Brokerage as a Principal-Agent Problem. Journal of Real Estate Finance and Economics, 1991, 4:2, 99-125.

Arnold, M.A. The Principal-Agent Relationship in Real Estate Brokerage Services. Real Estate Economics, 1992, 20:1, 89-106.

Benjamin, J.D., P. Chinloy, and D.T. Winkler. Labor Supply, Flexible Hours and Real Estate Agents. Real Estate Economics, 2009, 37:4, 747-67.

Chinloy, P. and D.T. Winkler. Contract Incentives and Effort. Journal of Real Estate Research, 2010, 32:4, 397-412.

- Contracts, Labor Supply and Income Targeting. Journal of Labor Research, 2011, 32:2, 113-35.

Clauretie, T.M. and N. Daneshvary. Principal-Agent Conflict and Broker Effort Near Listing Contract Expiration: The Case of Residential Properties. Journal of Real Estate Finance and Economics, 2008, 37:2, 147-61.

Coase, R.H. The Nature of the Firm. Economica. 1937, New Series, IV, 386-405.

Crockett, J.H. Competition and Efficiency in Transacting: The Case of Residential Real Estate Brokerage. Journal of the American Real Estate and Urban Economics Association, 1982, 10:2, 209-27.

Geltner, D.M., B.D. Kluger, and N.G. Miller. Optimal Price and Selling Effort from the Perspectives of the Broker and Seller. Real Estate Economics, 1991, 19:1, 1-24.

Jares, T.E., J.E. Larsen, and T.S. Zorn. An Optimal Incentive System for Real Estate Agents. Journal of Real Estate Research, 2000, 20:1-2, 49-59.

Jensen, M.C. and W.H. Meckling. Theory of the Firm: Managerial Behavior, Agency Costs and Ownership Structure. Journal of Financial Economics, 1976, 3, 305-60.

Johnson, K.H., L.V. Zumpano, and R.I. Anderson. Intra-firm Real Estate Brokerage Compensation Choices and Agent Performance. Journal of Real Estate Research, 2008, 30: 4, 421-40.

Miceli, T.J. The Optimal Duration of Real Estate Listing Contracts. Real Estate Economics, 1989, 17:3, 267-77.

- The Multiple Listing Service, Commission Splits, and Broker Effort. Real Estate Economics, 1991, 19:4, 548-66. 
The Welfare Effects of Non-price Competition among Real Estate Brokers. Real Estate Economics, 1992, 20:4, 519-32.

- Renegotiation of Listing Contracts, Seller Opportunism and Efficiency: An Economic Analysis. Real Estate Economics, 1995, 23:3, 369-83.

Miceli, T.J., K.A. Pancak, and C.F. Sirmans. Restructuring Agency Relationships in the Real Estate Brokerage Industry: An Economic Analysis. Journal of Real Estate Research, 2000, 20: $1-2,31-47$.

Is the Compensation Model for Real Estate Brokers Obsolete? Journal of Real Estate Finance and Economics, 2007, 35:1, 7-22.

Munneke, H.J. and A. Yavas. Incentives and Performance in Real Estate Brokerage. Journal of Real Estate Finance and Economics, 2001, 22:1, 5-21.

Waller, B.D., R. Brastow, and K.H. Johnson. Listing Contract Length and Time on Market. Journal of Real Estate Research, 2010, 32:3, 271-88.

White, H. A Heteroskedasticity-Consistent Covariance Matrix Estimator and a Direct Test for Heteroskedasticity. Econometrica, 1980, 48:4, 817-38.

Wu, C. and P.F. Colwell. Equilibrium of Housing and Real Estate Brokerage Markets under Uncertainty. Journal of the American Real Estate and Urban Economics Association, 1986, 14:1, 1-23.

Yavas, A. Seller-Broker Relationship as a Double Moral Hazard Problem. Journal of Housing Economics, 1995, 4, 244-63.

Yinger, J. A Search Model of Real Estate Broker Behavior. American Economic Review, 1981, $71: 4,591-605$.

Zorn, T.S. and J.E. Larsen. The Incentive Effects of Flat-Fee and Percentage Commissions for Real Estate Brokers. Journal of the American Real Estate and Urban Economics Association, 1986, 14:1: 24-47.

Zumpano, L.V., K.H. Johnson, and R.I. Anderson. Determinants of Real Estate Agent Compensation Choice. Journal of Housing Research, 2009, 18:2, 195-207.

We thank Paul Bishop and the NAR for providing the data for this study.

Daniel T. Winkler, University of North Carolina, Greensboro, NC 27402-6170 or dt_winkler@uncg.edu.

Bruce L. Gordon, University of North Alabama, Florence, AL 35632-0001 or blgordon@una.edu. 